\title{
The Judicial Repeal of the Johnson/Kennedy Administration's 'Signature' Achievement
}

\section{Citation}

Judge Nancy Gertner (Ret.), The Judicial Repeal of the Johnson/Kennedy Administration's 'Signature' Achievement (Mar. 9, 2014).

\section{Published Version}

http://dx.doi.org/10.2139/ssrn.2406671

\section{Permanent link}

http://nrs.harvard.edu/urn-3:HUL.InstRepos:16460375

\section{Terms of Use}

This article was downloaded from Harvard University's DASH repository, and is made available under the terms and conditions applicable to Open Access Policy Articles, as set forth at http:// nrs.harvard.edu/urn-3:HUL.InstRepos:dash.current.terms-of-use\#OAP

\section{Share Your Story}

The Harvard community has made this article openly available.

Please share how this access benefits you. Submit a story.

\section{Accessibility}


The Judicial Repeal of the Johnson/Kennedy Administration's "Signature" Achievement Judge Nancy Gertner (Ret.)

The Civil Rights Act of $1964,{ }^{1}$ which has been called "one of the most significant legislative achievements in American history" ${ }^{2}$ has been gutted. Responsibility lies not with Congress or an executive agency. For the most part, it is the third branch - the judges of the United States courts. Federal judges, from the trial courts to the Supreme Court, from one end of the country to the other, of all political affiliations, have interpreted the Act virtually, although not entirely, out of existence.

Many scholars have identified the pattern: Plaintiffs in discrimination cases tend to lose on summary judgment, more so than any other party in any other type of case. ${ }^{3}$ If they manage to get to trial and, significantly, if they convince a jury of their claims, their damage verdicts run a substantial risk of being reduced by trial judges, and their counsel's fees slashed - again more than the verdicts or fees of plaintiffs and plaintiffs' counsel in any other category of case. ${ }^{4} \mathrm{On}$ appeal, the story is even more striking: While summary judgment dismissals are overwhelmingly affirmed by appellate courts, even successful plaintiffs' verdicts are reversed more than jury verdicts in other types of cases. One has to pause at that statistic: It is one thing to reject a claim without giving plaintiffs the benefit of a jury determination; That result is troubling enough since discrimination cases involve the quintessential jury question, namely, "What is the defendant's motive in dismissing the plaintiff?" "Was the plaintiff denied a promotion 'because of' discriminatory animus?' But it is even more troubling to reject a jury's determination of damages, or worse, overturn its verdicts in a system that ostensibly values that decisionmaker above all.

It is not simply that plaintiffs lose but how they lose - in decision after decision that effectively legitimize discriminatory practices and behavior that would have been abhorrent when the Civil Rights Act was passed. ${ }^{5}$ In 1976, Fourteenth Amendment equal protection analysis was narrowed when the Supreme Court restricted it to intentional discrimination in Washington v. Davis. ${ }^{6}$ More recent cases suggest the willingness of the Court to apply the same or similar analysis to statutory discrimination claims. ${ }^{7}$ But even as limited to intentional discrimination, current case law is extraordinary. It appears to restrict or even reject a range of entirely competent evidence from which discriminatory intent may be inferred. It is ironic: Just

\footnotetext{
${ }^{1} 42$ U.S.C. § 2000e (2006). I deal here only with Title VII of the Civil Rights Act of 1964, which prohibits discrimination based on race, sex, religion and national origin.

${ }^{2}$ Landmark Legislation: The Civil Rights Act of 1964, UnITED STATES SENATE, http://www.senate.gov/artandhistory/history/common/generic/CivilRightsAct1964.htm (last visited Feb. 21, 2014).

${ }_{3}^{3}$ See Kevin M. Clermont \& Stewart J. Schwab, Employment Discrimination Plaintiffs in Federal Court: From Bad to Worse?, 3 HARV. L. \&POL'Y REV. 103, at 108-14 (2009).

${ }^{4}$ Alan David Freeman, Legitimizing Racial Discrimination Through Antidiscrimination Law: A Critical Review of Supreme Court Doctrine, 62 MinN. L. REV. 1049 (1978).

${ }^{5}$ Id. at 1054-56 (1978) [hereinafter Freeman, Legitimizing Racial Discrimination] (identifying the extent to which discrimination law, by focusing only on the individual perpetrator, legitimized all other discrimination and failed to focus on discrimination's root causes).

${ }^{6}$ Washington v. Davis, 426 U.S. 229 (1976).

${ }^{7}$ See, e.g., Ricci v. DeStefano, 557 U.S. 557 (2009) (curtailing disparate impact in Title VII litigation).
} 
as the social-psychological literature identifies implicit race and gender bias - in organizational settings, in apparently neutral evaluative processes, and among decisionmakers of different races or gender - federal discrimination law moves in the opposite direction, trivializing even evidence of explicit bias. ${ }^{8}$

I want to understand why: (1) Is it a matter of ideology, in the sense of a system of beliefs fueled more and more by a more conservative Supreme Court and adopted by judges across the country? Do they simply accept the view that we are in a post racial, post gendered society? As others and I have described elsewhere, it is as if the bench is saying in its opinions:

"Discrimination is over. The market is bias-free. The law's job is to find the truly aberrant actor who just didn't get the memo." 9 The phenomenon that is discrimination can be reduced to a simple paradigm - explicitly discriminatory policies and rogue individuals. If a case does not precisely reflect those facts - and few do in the $21^{\text {st }}$ century - they are without merit. Surely some judges, if pressed, would agree with this position, but does it adequately explain the antidiscrimination plaintiff bias across the country, at all levels - not just the fact of dismissal but the content of the decisions?

(2) Is that ideological perspective in fact true? Are most federal cases frivolous, with dismissals roughly commensurate with the numbers of insubstantial cases? According to this view, employment discrimination law has worked. The market is bias-free, leaving litigation only for the extreme, the explicit, the aberrant cases. Judges are appropriately reflecting the progress that discrimination law has reaped. Statistics about wage disparity as between women and men, blacks and whites, about the persistence of the "glass ceiling" for women, about maternal discrimination, to name a few, however, suggest otherwise. ${ }^{10}$

\footnotetext{
${ }^{8}$ See, e.g., John T. Jost et al., The Existence of Implicit Bias is Beyond Reasonable Doubt: A Refutation of Ideological and Methodological Objections and Executive Summary of Ten Studies that No Manager Should Ignore, 29 RES. ORGANIZATIONAL BEHAV. 39 (2009)(discussing ten recent studies demonstrating implicit bias with respect to race, ethnicity gender, and social class). For discussions of the failure of the courts to address these issues, see Samuel R. Bagenstos, Implicit Bias, “Science,” and Antidiscrimination Law, 1 HARV. L. \& POL'Y REV. 477 (2007); Samuel R. Bagenstos, The Structural Turn and the Limits of Antidiscrimination Law, 94 CALIF. L. REV. 1 (2006); and Linda Hamilton Krieger \& Susan T. Fiske, Behavioral Realism in Employment Discrimination Law: Implicit Bias and Disparate Treatment, 94 CALIF. L. REV. 997 (2006).

${ }^{9}$ Nancy Gertner, Losers' Rules, 122 YALE L. J. ONLINE 109, 111 (2012), http://yalelawjournal.org/images/pdfs/1111.pdf.

${ }^{10}$ MAJORITY StAFF OF JOINT ECON. COMM., 111TH CONG., WOMEN AND THE ECONOMY 2010: 25 YEARS OF PROGRESS BUT CHALLENGES REMAIN 1 (2010) (noting that in 2009 the weekly wage for a woman was, on average, eighty percent of a comparable man's wages); Nathan Berg \& Donald Lien, Measuring the Effect of Sexual Orientation on Income: Evidence of Discrimination?, 20 CONTEMP. ECON. POL'Y 394, 394 (2002) (examining wages from 1991 to 1996 and finding that nonheterosexual men earn twenty-two percent less than heterosexual men, while nonheterosexual women earn thirty percent more than heterosexual women); Marianne Bertrand \& Sendhil Mullainathan, Are Emily and Greg More Employable than Lakisha and Jamal? A Field Experiment on Labor Market Discrimination, 94 AM. ECON. REV. 991, 1006-07 (2004); Catherine Rampell, Older Workers Without Jobs Face Longest Time out of Work, N.Y. TIMES: ECONOMIX (May 6, 2011, 6:27 PM), http://economix.blogs.nytimes.com/2011/05/06/older-workers-without-jobs-face-longest-time-out-of-work (observing that the typical duration of unemployment increases with age and is at an all-time high for those over fifty-five).
} 
(3) Or is it simply selection bias in the federal courts? Have decades of narrowing discrimination law, rightly or wrongly, led plaintiffs' counsel to choose state court over federal, thereby skewing the federal pool. Recent studies suggest that federal discrimination filings have declined; plaintiffs are literally voting with their feet to more responsive state courts. ${ }^{11}$ The cases remaining in federal court, according to this view, are the least substantial ones. And even among the cases in federal court, so the argument goes, the better cases are settled leaving the weak ones at the mercy of summary judgment motions and vulnerable verdicts. ${ }^{12}$ Does selection bias fully account for the numbers of cases dismissed, verdicts slashed or overturned, or the reasoning of the decisions in these cases? The substantive law of discrimination - the fact patterns described in the case law and then rejected by the courts as not amounting to discrimination even on a forgiving summary judgment standard - suggest that something else is afoot. At least as described in opinions, many of these cases are not insubstantial for summary judgment purposes. They include, for example, narratives of the use of the n-word, of sexual harassment, even stalking the plaintiff, which a jury might accept or reject, consider pervasive or minor - yet they are rejected by the courts.

(4) Some federal judges have insisted that the national patterns reflect nothing more than their fealty to the law. The Supreme Court law has set a high bar for discrimination cases, they insist; they are just following that lead. With respect to procedural rules, like the standards governing statutes of limitations, ${ }^{13}$ or perfecting a claim of sexual harassment, i.e. whether the plaintiff complained to her supervisor about co-worker sexual harassment, ${ }^{14}$ they have no discretion. But the procedural rules that bar the plaintiff's claims do not fully account for the national trends - for courts making subjective judgments rejecting sexual harassment claims because they are not sufficiently "severe and pervasive" to be actionable ${ }^{15}$ or dismissing racist or sexist remarks as merely "stray remarks," not reflecting bias. No binding precedent obliges a court to minimize such testimony, to "slice and dice" evidence of discrimination, and reject it out of hand. ${ }^{16}$

(5) Are there pressures (or implicit biases) that cut across political affiliation and ideology to affect judges in their subjective judgments about what is or is not discrimination? One pressure is what Professor Judith Resnik has called the pressure to be a managerial judge ${ }^{17}$

\footnotetext{
${ }^{11}$ Clermont \& Schwab, supra note 3, at 104.

${ }^{12}$ Mark Galanter, Why the "Haves” Come Out Ahead: Speculations on the Limits of Legal Change, 9 LAW \& SoC'Y REV. 95, 101 (1974) (describing selection bias in general with respect to settled cases).

${ }^{13}$ See, e.g., Ledbetter v. Goodyear Tire \& Rubber Co., Inc., 550 U.S. 618, 642-43 (2007) (holding that the statute of limitations for disparate pay claims extends expires 180 days after the moment of a discriminatory pay decision, even if the disparate pay continues beyond the limitations period), superseded by statute, Ledbetter Fair Pay Act, Pub. L. No. 111-2, 123 Stat. 5 (2009).

${ }^{14}$ See Burlington Indus., Inc. v. Ellerth, 524 U.S. 742, 765 (1998) (holding that an employer could avoid liability for workplace sexual harassment if "the plaintiff employee unreasonably failed to take advantage of any preventive or corrective opportunities provided by the employer").

${ }^{15}$ See Harris v. Forklift Sys., Inc., 510 U.S. 17, 21 (1993) ("Conduct that is not severe or pervasive enough to create an objectively hostile or abusive work environment-an environment that a reasonable person would find hostile or abusive-is beyond Title VII's purview.").

${ }^{16}$ Michael J. Zimmer, Slicing \& Dicing of Individual Disparate Treatment Law, 61 LA. L. REV. 577 (2001) (discussing the different ways that a judge will "slice and dice" the evidence to fit into the existing summary judgment standards).

${ }^{17}$ Judith Resnik, Managerial Judges, 96 HARV. L. REV. 376, 379, 407 (1982).
} 
which has created a culture in which judges are encouraged to resolve cases without trials, in which formal opinions are to be avoided, and in which the high transaction costs associated with civil litigation may well be seen as more important than redressing inequality. ${ }^{18}$ Put otherwise, under this approach to judging, courts are more concerned with false positives, the wrongful accusation of bias, and the litigation costs accompanying it, than false negatives, an unredressed claim of discrimination. They are bound to err on the side of rejecting discrimination claims in making the judgments the law encourages them to make.

These patterns are then reflected in, and exacerbated by, a phenomenon I have described recently as "Losers' Rules":

Asymmetric decisionmaking - where judges are encouraged to write detailed decisions when granting summary judgment and not to write when denying itfundamentally changes the lens through which employment cases are viewed, in two respects. First, it encourages judges to see employment discrimination cases as trivial or frivolous, as decision after decision details why the plaintiff loses. And second, it leads to the development of decision heuristics-the Losers' Rules - that serve to justify prodefendant outcomes over and over again, exacerbating the one-sided development of the law. ${ }^{19}$

The law of discrimination becomes more and more skewed now not only with procedural rules defining when to sue, or to whom to complain, but substantive standards that judges simply choose to apply in ways that disadvantage plaintiffs - doctrines like "stray remarks" that excuse explicitly biased statements, "honest belief" in which the court characterizes the employer as being in good faith, or judicial determinations of when harassment is "severe and pervasive."20 Make no mistake: The law does not mandate any particular outcome in these cases; no judge is required by law to trivialize a racist or sexist remark, or excuse a pattern of conduct. But judges

\footnotetext{
${ }^{18}$ Elizabeth M Schneider \& Hon. Nancy Gertner, "Only Procedural”: Thoughts on the Substantive Law Dimensions of Preliminary Procedural Decisions in Employment Discrimination Cases, 57 N.Y.L. SCH. L. REV. 767, 777-78 (2013).

${ }^{19}$ Gertner, supra note 9, at 110.

${ }^{20}$ For example, in Shorter v. ICG Holdings, Inc., 188 F.3d 1204 (10th Cir. 1999), the court held that a supervisor calling the plaintiff an "incompetent nigger" was not actionable because this derogatory slur was a "personal opinion" and therefore not "directly" related to the supervisor motive for firing the plaintiff. Id. at 1206-08. The court approvingly cited Heim v. Utah, 8 F.3d 1541, 1546-47 (10th Cir. 1993), in which the defendant had remarked, "I hate having fucking women in the office" and the court concluded that this comment was not direct evidence of discriminatory intent. To be sure, both cases predated Desert Palace, Inc. v. Costa, 539 U.S. 90,92 (2003), which held that the plaintiff need not provide direct evidence of discrimination to shift the burden of proof to the employer in mixed-motive cases. But the conclusions that these statements did not directly reflect discriminatory animus are still extraordinary. Similarly, courts rely on the doctrine of "honest belief" to dismiss discrimination claims when an employer claims that a wrong discriminatory belief was "honest" or "honestly described," even if this explanation appears pretextual or baseless. See Gustovich v. AT\&T Commc'ns, Inc., 972 F.2d 845, 848-49 (7th Cir. 1992); see also Kariotis v. Navistar Int'1 Transp. Corp., 131 F.3d 672, 677 (7th Cir. 1997) (stating that the issue is not whether "the employer's reasons for a decision [were] 'right but whether the employer's description of its reasons [was] honest"” (quoting Gustovich, 972 F.2d at 848)); Fischbach v. D.C. Dep't of Corr., 86 F.3d 1180, 1183 (D.C. Cir. 1996) (stating that courts review not " "the correctness or desirability of [the] reasons offered ... [but] whether the employer honestly believes in the reasons it offers." (alterations in original) (quoting McCoy v. WGN Cont'l Broad. Co., 957 F.2d 368, 373 (7th Cir. 1992)).
} 
regularly do so, dismissing cases or reversing verdicts, and if they do, they are likely to be affirmed by the appellate courts.

If there are nonideological pressures that are skewing the outcome in these cases, how can they be changed? The disclosure of discrimination patterns on a judge by judge basis might well make a difference. Take sentencing, for example: Federal judges strongly resisted the disclosure of the sentencing practices and patterns of individual judges, for fear it would unleash a political backlash. The Sentencing Commission kept that information, but only provided it when an individual judge requested it. Indeed, so resistant were the judges to this disclosure that they specifically negotiated with the Sentencing Commission to protect their confidentiality. ${ }^{21}$ Looking at civil rights cases, would it matter to a judge if statistics showed that he or she dismissed $100 \%$ of discrimination cases in a two-year period as one study in the Northern District of Atlanta has shown? Or is the discrimination enforcement system so skewed, judicial attitudes so ossified, that we should entirely reconsider the private attorneys' general/private lawyer model of enforcement? Should we look again at an adjudicative agency, like the National Labor Relations Board, or an executive agency with more robust powers than the Equal Employment Opportunity Commission? All that is clear is that the current system - private lawsuits, judicial enforcement - is flawed. ${ }^{22}$

I first outline the data on employment discrimination cases and the decisional law. I then consider the various explanations for the patterns, and finally, I provide tentative suggestions for change.

\section{A. The Data}

\section{a. A first step: The Georgia study}

The Atlanta firm of Barrett and Farahany commissioned a study of the 2011 and 2012 employment summary judgment orders from the Northern District of Georgia, the results of which surely bear careful consideration. ${ }^{23}$ Of the 181 cases (in which the plaintiff had counsel), the Court dismissed $95 \%$ of them at least in part and $81 \%$ of the cases in full. Racial hostile work environment claims were dismissed $100 \%$ of the time. Data broken down per judge revealed that some judges had dismissed all discrimination cases in the two-year period and that when the magistrate judge recommended dismissal, the judge followed $100 \%$ of the time. Data also suggested that white plaintiffs alleging reverse discrimination had a better success rate than black plaintiffs alleging discrimination.

To be sure, there are limitations to the study; it is only a starting point. The sample was restricted to a two-year period with a relatively small number of cases per judge; plainly, a

\footnotetext{
${ }^{21}$ Hon. Nancy Gertner, Judge Identifiers, TRAC, and a Perfect World, 25 FED. SENT'G REP. 46, 47 (2012).

${ }^{22}$ There of course may be other explanations for these skews in the case law, such as uneven access to quality representation, which in turn prevents judges from citing and expanding on good case law. See Scott A. Moss, Bad Briefs, Bad Law, Bad Markets: Documenting the Poor Quality of Plaintiffs' Briefs, Its Impact on the Law, and the Market Failure It Reflects, 63 EMORY L.J. 59 (2013).

${ }^{23}$ Amanda Farahany \& Tanya McAdams, Analysis of Employment Discrimination Claims for Cases in Which an Order was Issued on Defendant's Motion for Summary Judgment in 2011 and 2012 in the U.S. District Court for the Northern District of Georgia, http://ssrn.com/abstract=2326697 (September 16, 2013).
} 
longer-term view is necessary to identify meaningful trends. Researchers need to understand the entire pool of cases, which cases are settled and why. Are the better cases appropriately resolved by competent counsel, or are they settled "in the shadow of" 24 a substantive law so skewed against the plaintiff or judicial hostility so clear that any settlement is better than nothing. The bottom line, however, is that while the N.D. of Georgia numbers for dismissals were higher than the national figure, namely $80-100 \%$ dismissal rates, there is no question that it reflects that national pattern; study after study has shown high dismissal rates across the country on summary judgment. $^{25}$

Research is presently underway to look at these issues across a number of courts. We plan to evaluate six courts as Farahany and McAdams have done in the N.D. Ga - Alabama and other districts in Georgia, states without analogous state discrimination laws. In addition, we will examine Florida as well as Massachusetts, Chicago and San Francisco. We plan to ask the questions described at the outset of this paper: Are there some district courts that, like the N.D. Georgia, have a $100 \%$ dismissal rate? Some district court judges? Are there regional differences? Do caseload differences account for these differences as between district courts or regions? Does the fact that there is no analogous state discrimination law affect these numbers? What if data suggests that precisely in the regions of the country with a history of discrimination, the rate of dismissal is the highest and the language of the decisions most forgiving? What if those patterns are reinforced by decisions of the circuit courts?

\section{b. Reversals of trial verdicts}

Some may say that without carefully evaluating the merits of both the dismissed cases and the settled cases, there is no way of knowing if the patterns described above are fair, weeding out the insubstantial cases and resolving the substantial ones? As I describe below, an analysis of summary judgment opinions surely raises concerns that this is not so, that district court judges are drawing lines about what is or is not discrimination in a way that fundamentally changes, even skews the substantive law of discrimination against plaintiffs. And that substantive law plainly has an impact on settlement practices.

But even if one assumed that settlements and summary judgment dismissals appropriately separate the meritorious cases from those that are not, the statistics about the judicial treatment of plaintiffs' verdicts suggest a different pattern. More discrimination plaintiffs' verdicts are reduced on remittitur than the verdicts in any other case. ${ }^{26}$ And this pattern continues at the appellate level. Favorable plaintiffs' verdicts fare worse on appeal than do other litigants', as a 2009 study by Professor Kevin Clermont and Stewart J. Schwab found. ${ }^{27}$ The 2009 Clermont and

\footnotetext{
${ }^{24}$ Catherine Albiston, The Rule of Law and the Litigation Process: The Paradox of Losing by Winning, 33 LAW \& SOC'Y REV. 869, 872 (1999).

${ }^{25}$ For example, a 2007 report by the Federal Judicial Center noted that 74 to 77 percent of all summary judgment motions ruled on in employment discrimination cases were granted in whole or in part in 2006 - more than for any other type of case studied. See Memorandum from Joe Cecil \& George Cort, Fed. Judicial Ctr., to Judge Michael Baylson, U.S. Dist. Court for the E. Dist. of Pa. 7 tbl.4 (Nov. 2, 2007), https://bulk.resource.org/courts.gov/fjc/insumjre.pdf.

${ }^{26}$ See Suja A. Thomas, Re-Examining the Constitutionality of Remittitur Under the Seventh Amendment, 64 OHIO ST. L.J. 731, 746 (2003).

${ }^{27}$ Clermont \& Schwab, supra note 3, at 108-14.
} 
Schwab study of reversal rates reports that "[a]ll the circuits showed . . . anti-plaintiff effect," and grouped the Tenth, Fourth, Second, Ninth, Eleventh, and First as having approximately the same difference between defendant and plaintiff dismissals. ${ }^{28}$

That jury losses are affirmed on appeal is not unusual since appellate courts will defer to verdicts. More stunning is the fact that appellate courts reverse plaintiffs' trial wins far more often than defendants' wins. $^{29}$

\section{c. Legitimizing Discrimination}

While the rate of losses is important, more critical is the way plaintiffs lose. By making pronouncements about what is or is not discrimination or a hostile work environment, courts have legitimized practices that would have horrified the early supporters of the Act. ${ }^{30}$ Consider cases involving the $\mathrm{N}$-word:

In Johnson v. Freese, a case in the N.D. of Georgia, the Todds, African-Americans who sued the Whortons, white owners of the club where they worked, for creating a racially hostile environment. ${ }^{31}$ The defendants moved for summary judgment, which the judge granted on these facts (considered in the light most favorable to the plaintiffs): At manager meetings, Mr.

Whorton directed the $\mathrm{N}$-word to the plaintiffs, despite their objections. He called a staff meeting to talk about his use of the $\mathrm{N}$-word, explaining that he was too old to change and inviting anyone who did not like it to quit. He made comments like: "What do your people want? When this was a white club, my customers used ashtrays. Ever since the n-----s have been in the club, the cigarettes have been put out on the floor. The difference between blacks and n-----s is that n-----s put their cigarettes out on the floor." And, do "days like this [make] you wish you people had stayed in chains?" He asked someone wearing a shirt with a monkey on it, "Are the Obama shirts in?" and complained to Mr. Todd that he could not trust African-Americans. ${ }^{32}$

But to the Georgia federal court this was not enough. No reasonable jury, the court held, could find a racially hostile environment. In language that the supporters of the Civil Rights Act would have found shocking, the court added, while "the facts simply show that the Whortons are racist, bigoted, and/or offensive people" not all "profane or [racist] language or conduct will constitute discrimination in the terms and conditions of employment." None of these incidents went beyond the "ordinary tribulations of the workplace." The decision, a Final Report and Recommendation of a United States Magistrate Judge, was adopted by the trial judge without comment, no objections having been filed.

To be sure, there were weaknesses in the case. The setting was a black nightclub with white owners, and although the court is not explicit, the clear message is that the owner's language could not have been particularly shocking to the employees given the language of the

\footnotetext{
${ }^{28} I d$. at 119 n. 47.

${ }^{29}$ Between 1988 and 2004, appellate courts reversed over 40 percent of trial judgments for plaintiffs in employment discrimination cases, compared to under 9 percent of defendant wins. Id. at 110 tbl.2 (2009).

${ }^{30}$ Freeman, Legitimizing Racial Discrimination, supra note 4, at 1054-55.

${ }^{31}$ See Johnson v. Freese, No. 1:10-CV-481 (N.D. Ga. June 17, 2011), Final Report and Recommendation available at http://media.cmgdigital.com/shared/news/documents/2013/10/17/Johnson_v._Freese.pdf.

${ }^{32}$ Id. at 7.
} 
patrons. Still, the plaintiff could argue that this language coming from a white boss had a different resonance to the African-American workers, than the conversation among their peers. Or they could argue that given the numbers of comments and their content (about slavery, about President Obama), the boss simply went too far. Summary judgment, after all, is not supposed to be about screening the cases that - in the judgment of the bench - are likely to lose before a jury, making credibility determinations, weighing the evidence in the favor of one party or another. It is a lower bar -- determining that there is no issue of material fact, after considering all of the inferences in favor of the non-moving party. ${ }^{33}$

Racist comments in the workplace had been "ordinary" and "commonplace" when the Civil Rights Act was enacted. Even if social norms have changed in the decades since 1964, even if language courts once found wholly unacceptable has become regular currency, the law was amended in 1991 so that those judgments would be made by a jury. ${ }^{34}$ A representative jury was supposed to consider the facts, not a judge whose last employment in the private sector may have been decades ago, who-looking at the federal bench's composition-was likely to be white, male, a former partner in a big firm, or a former prosecutor.

In fact, in several cases in which allegations of the use of the $\mathrm{N}$-word went to a jury, juries found for the plaintiffs. For example, a Buffalo, New York jury awarded \$25 million in damages to a steelworker whose coworkers repeatedly called him the N-word and other slurs. The jury heard evidence that the employer took remedial action, such as suspending offending employee without pay, installing lights in the parking lot after a toy monkey was hung from a noose beside the plaintiff's car, and assigning an escort to protect the plaintiff. Nonetheless, the jury elected to award over \$25 million in damages against the corporate defendant, including \$24 million in punitive damages. ${ }^{35}$ In 2011 , a jury awarded $\$ 300,000$ to a personal trainer who claimed that other trainers at a sports club had repeatedly called him the N-word. ${ }^{36}$ The sports club presented evidence that it dismissed the plaintiff because the plaintiff had used similar racially-offensive language against Latino trainers. Nonetheless, the jury awarded $\$ 300,000$ on the hostile-work-environment claim. More recently, juries have awarded damages in the amount of \$300,000 in Bennett v Riceland Foods, Inc., ${ }^{37}$ over \$300,000 in Weatherly v. Alabama State University $^{38}$ and \$250,000 in Johnson v. Strive East Harlem Employment Group. ${ }^{39}$

By comparison, judges on summary judgment often hold that racial epithets did not establish a hostile work environment by characterizing these statements as "stray remarks" or

\footnotetext{
${ }^{33}$ Celotex Corp. v. Catrett, 477 U.S. 317, 322 (1986) (quoting FED. R. CIV. P. 56(c)).

${ }^{34}$ Civil Rights Act of 1991 (Pub. L. 102-166).

35 Turley v. ISG Lackawanna, Inc., 06-CV-794S, 2013 WL 150382 (W.D.N.Y. Jan. 14, 2013). The district court upheld the $\$ 1$ million compensatory damages award but ordered a new trial on punitive damages unless the plaintiff accepted reduced punitive damages of $\$ 5$ million.

${ }^{36}$ Abel v. Town Sports Int'l, LLC, 09 Civ. 10388(DF), 2012 WL 6720919 (S.D.N.Y. Dec. 18, 2012).

37 721 F.3d 546, 551 (8th Cir. 2013).

38728 F.3d 1263, 1269 (11th Cir. 2013). Significantly, the same judge who had adopted the Magistrate's finding in the Todd v. Freese case (when no objections had been filed) was also on the panel in the Alabama State case, affirming a jury verdict in the plaintiffs' favor.

${ }^{39}$ No. 12-4460 (S.D.N.Y. Jan. 15, 2014) (order on defendant motion for new trial). The trial court later ordered a new trial unless the plaintiff agreed to a reduced compensatory award of $\$ 128,109.59$, see id. at *1, but also awarded $\$ 173,252.73$ in attorneys' fees and costs. See Johnson v. Strive East Harlem Employment Group, No. 12-4460 (S.D.N.Y. Jan. 28, 2014) (order on attorneys' fees and costs).
} 
concluding that even repeated use of epithets is not evident of "pervasive and severe" racial hostility. The Whorton decision, despite its unique facts and unique weaknesses, is not an aberration. ${ }^{40}$ For example, in Oladokun v. Grafton Sch., Inc., ${ }^{41}$ the District of Maryland granted summary judgment for the defendant on claims of discrimination against African-American employees at a private school for intellectually and physically disabled children. A supervisor had told the plaintiff that "I will get you n-----s out of here," and had also said to a child client at the facility, "Don't slobber on me, slobber on that black n----- over there," referring to a coworker. The court held that these remarks were not "not sufficient to satisfy the hostile work environment test" because they were "not sufficiently pervasive." 42 Similarly, in Dotson v. $G u l f,{ }^{43}$ a supervisor told a longshoreman employee in response to his leaving early for a lunch break, "You n-----s just don't want to do right." The supervisor fired the employee immediately on the spot, though the employee was later allowed to return to work. The court held that these "incidents of a patently offensive slur, while rude and upsetting, are insufficient to affect the terms or condition of Dotson's employment.",44

It is not just racist speech that is acceptable; so is sexist speech. The "stray remarks" doctrine trivializes sexist (and racist) comments. They are "not evidence of discrimination" at all. Or they are the speaker's "personal opinion," - as if that eliminates their poisonous impact on the work environment. Or they were not so "severe and pervasive" as to create a hostile environment. What kinds of sexist remarks are dismissed in this fashion? Where plaintiff's supervisor repeatedly referred to her as, among other things, a "dumb sh-t[,]" "whore[,]" "stupid bitch" and "hooker," the district court dismissed the case because the conduct was a type of "general vulgarity that [the law] does not regulate." a female deputy sheriff even though, over a four-year period, the supervisor made inappropriate comments, invited her to sit on his lap, kissed her on the buttocks (which the court describes as

\footnotetext{
${ }^{40}$ See, e.g., Nicholson v. City of Clarksville, Tenn., 530 F. App’x 434 (6th Cir. 2013) (“isolated incidents of general profanity" and a "few incidents involving racial slurs" are not sufficient to amount to the kind of "extreme" conduct that changes the terms and conditions of employment). $C f$. Ayissi-Etoh v. Fannie Mae, 712 F.3d 572 (D.C. Cir. 2013) (majority reverses summary judgment on claims including use of the $\mathrm{N}$-word).

${ }^{41} 182$ F. Supp. 2 d 483 (D. Md. 2002).

${ }^{42} I d$. at $493-94$.

${ }^{43}$ Civ.A. H-05-0106, 2006 WL 44071, at*13 (S.D. Tex. Jan. 9, 2006).

${ }^{44}$ Id. at *13. See also Alexander v. Opelika City Sch., 352 F. App'x 390 (11th Cir. 2009) (affirming lower court grant of summary judgment as not sufficiently "severe and pervasive," where African-American employee could "only" recall eight instances over the course of two years where he was called "boy" by his supervisor); Ash v. Tyson Foods, Inc., 190 F. App'x 924, 926 (11th Cir. 2006) (plant manager's use of the word "boy" to refer to African-American employees not sufficient to provide a basis for a jury to determine pretext where they were, in part, "stray remarks"); White v. Geico, 457 F. App'x 374 (5th Cir. 2012) (no hostile work environment despite references to a client as "n word," characterizing one of the offices as a "ghetto," or "FEMA trailer," reference to another African-American worker as someone who "always wanted to be a white female"); Williams v. CSX Transp. Co., 643 F.3d 502 (6th Cir. 2011) (affirming the dismissal on summary judgment where plaintiff, the only AfricanAmerican and the only woman in a four person office, as told by two supervisors "that she was a Democrat only because she was a black woman," that this country should get rid of Al Sharpton and Jesse Jackson because without those two "monkeys" this country would be "a whole lot better," that she should return to school because she would not have to pay for her education as a single black mother, and that an "unmarried woman cannot "have the love of God in their heart[s]").

${ }^{45}$ Shorter v. ICG Holdings, Inc., 188 F.3d 1204 (10th Cir. 1999) (addressing the question of whether derogatory comments were direct evidence of discrimination, rather than circumstantial evidence), abrogated by Desert Palace, Inc. v. Costa, 539 U.S. 90, 98-102 (2003).
} 
"allegedly kissing her on her clothed backside"). ${ }^{46}$ Nor did an employee whose manager "touched her inappropriately on two occasions by putting his hand on her crotch" confront "an objectively or subjectively hostile work environment," because there was evidence that she herself had "used vulgar, profane language, told dirty jokes, graphically discussed her sex life and engaged in sexual banter." 47 Nor in the case of a male coworker who called the plaintiff "a perra," a Mexican expletive that translates to 'bitch,' 'whore,' or 'person paid for sex,' called her stupid, grabbed his crotch, made an offensive hand gesture that signified the ' $\mathrm{f}$ word,' and spit on the floor." 48

\section{Tentative Conclusions}

What is the reason for these patterns? First, as others have written, is the problem ideological, the overarching sense that we are at the dawn of the post-racial, post-sexist society? The 1964 Civil Rights Act, while once important, is seen as unnecessary today. ${ }^{49}$ Surely, this is the message communicated by the Supreme Court. Have explicit cues from a more conservative Supreme Court (Ledbetter, etc.) percolated down to the lower federal courts? ${ }^{50}$

Second, is it true that the law has done its job? The market works, and only needs to be tweaked at the margins, as the case law suggests. The data is otherwise: "Every measure of economic success reveals significant racial inequality in the U.S. labor market." 2009 Data show that people of color make up 34 percent of the private sector workforce, but hold only 11 percent of senior or executive positions. ${ }^{52}$ In 2010, the median weekly earnings for full-time employees varied significantly by race and gender: for white men, the average was $\$ 850$ a week, while for Black men that number dropped to $\$ 633$ and Hispanic men still lower, at $\$ 560$ per week. ${ }^{53}$ Social psychologists, organizational behavioralists and labor economists suggest that the reason for these patterns is that racial and gender bias - implicit or explicit - continues to play a significant role in the allocation of jobs.

Is it selection bias, not merely the impact of the settled cases on the pool of federal cases, but also the impact of a more welcoming state court on federal filings. ${ }^{54}$ This would mean that

\footnotetext{
${ }^{46}$ Final Report and Recommendation at 27-30, Lindquist v. Fulton County, No. 1:09-cv-01102-RWS (N.D. Ga. Nov. 23, 2010) (No. 88).

${ }^{47}$ Derrico v. Pinkerton's, Inc., No. 97 C 5851, 1999 WL 311757, at *4 (N.D. Ill. May 12, 1999).

${ }^{48}$ Colon v. Envtl. Tech., Inc., 184 F. Supp. 2d 1210, 1214 (M.D. Fla. 2001).

${ }^{49}$ See generally Trina Jones, Anti-Discrimination Law in Peril?, 75 Mo. L. REV. 423 (2010); see also Helen Norton, The Supreme Court's Post-Racial Turn Towards a Zero-Sum Understanding of Equality, 52 WM. \& MARY L. REV. 197, 223-28 (2010).

${ }^{50}$ See Simon Lazarus, Stripping the Gears of National Government: Justice Stevens 's Stand Against Judicial Subversion of Progressive Laws and Lawmaking, 106 Nw. U. L. REV. 769, 771 (2012) (describing the techniques employed by the Supreme Court to dismantle progressive laws since Justice Rehnquist in 1986).

${ }^{51}$ Bertrand \& Mullainathan, supra note 10.

522009 Job Patterns for Minorities and Women in Private Industry, EQUAL EMPLOYMENT OPPORTUNITY COMMISSION, available at http://www1.eeoc.gov/eeoc/statistics/employment/jobpat-eeo1/2009/ (last visited Feb. 21, 2014).

${ }^{53}$ U.S. DEP'T. OF LABOR, MEDIAN WEEKLY EARNINGS OF FULl-TimE WAGE AND SALARY WORKERS BY SEX, RACE, AND HISPANIC OR LATINO ETHNICITY, 1979-2010 ANNUAL AVERAGES 41 (2011), available at http://www.bls.gov/cps/cpsrace2010.pdf.

${ }^{54}$ Clermont \& Schwab, supra note 3 , at 107-08.
} 
the cases in federal court are in fact the less substantial ones, brought by counsel who did not realize how inhospitable the federal courts were. Whatever the validity of state law, it would not apply to the Northern District of Georgia, for example, or in Alabama, the other state that does not have a parallel state statute prohibiting discrimination by race. ${ }^{55}$ Second, it does not necessarily account for the facts as reflected in the decisional law - allegations of explicit bias rejected by courts, or minimized in the outcome.

Is it simply a reflection of more unforgiving rules from the Supreme Court - quite apart from the ideology these rules reflect? When the Northern District of Georgia article was published, one reaction was that these cases are dismissed because judges are simply "following the law." 56 That may well be true, when certain of the Supreme Court's procedural rules are considered - rules on statutes of limitations in employment cases, rules requiring reporting harassment to a supervisor before an employer can be held accountable for coworker harassment. ${ }^{57}$ If there are no allegations within the limitations period or the appropriate person received the complaint, the judge has no discretion but to dismiss the case. ${ }^{58}$ During a yearly panel held by the United States District Court, a lawyer asked the judges, "Why are the federal courts so hostile to discrimination claims?" The judges to a person insisted there was no hostility, that they were just obliged to follow the law.

But the "law" does not compel the granting of summary judgment in many of the reported cases involving "stray remarks," or the standard for "severe and pervasive" harassment. Employment discrimination cases are factually complex, deal with state of mind issues to be proved circumstantially and are rarely uncontested. The summary judgment legal standards are general, rarely mandating a certain result, as would a claim involving a statute of limitations issue or the failure to exhaust administrative remedies. Judges are deciding these cases not because they are forced to do so by precedent, but because they choose to do so.

Is the explanation in the pressures on the bench that cross ideological lines, pressures that have fundamentally changed the federal bench and have had a singular impact on employment cases? Professor Judith Resnik has described the problem of managerial justice. ${ }^{59}$ Judges are encouraged to resolve cases without trials, to use alternative dispute resolution or to mediate the

\footnotetext{
55 See State Laws on Employment-Related Discrimination, NATIONAL CONFERENCE OF STATE LEGISLATURES, (Jan. 2014), http://www.ncsl.org/research/labor-and-employment/discrimination-employment.aspx. While all 50 states have some laws prohibiting employment-related discrimination, the Alabama statute does not cover discrimination based on race and the Georgia statute only covers discrimination based on race in state employment.

${ }^{56}$ See Richard Kopf, Kopf's additional response to Ms. Farahany, HeRCULES AND THE UMPIRE (Nov. 1, 2013), http://herculesandtheumpire.com/2013/11/01/kopfs-additional-response-to-ms-farahany/ ("The fact is that the law on summary judgment motions in employment cases favors the granting of summary judgment motions in a high percentage of the cases and, not surprisingly, that is what you see happening in the Northern District of Georgia and with 'yours truly' too.").

${ }^{57}$ See supra note 14.

${ }^{58}$ Of course, these restrictions could be equitably waived when a plaintiff shows that there is a "continuing violation," a doctrine which judges have chosen to apply using the same approaches as their approaches to the merits. See, e.g., Cordero-Suarez v. Rodriguez, 689 F.3d 77, 83 (1st Cir. 2012) (Court finds no continuing violation because there is no "anchoring" violation in the limitations period, discounting evidence that after the plaintiff was transferred because of harassment, the harasser continued to visit her new officer, that she continued to complain of the harassment, that he threatened her by saying that he "would not rest until [she] was permanently dismissed from the Treasury Department.")

${ }^{59}$ Resnik, supra note 17, at 379, 407.
} 
cases themselves. Formal written opinions are to be avoided; the author was told during a judicial training session that "if you wrote an opinion," you failed. If you could not settle the case, write your decision as a margin note on the pleading or announce it in open court, more efficient but hardly creating a meaningful precedent.

These pressures are mirrored in, and exacerbated by, a phenomenon I have described recently as "Losers' Rules." When the defendant successfully moves for summary judgment in a discrimination case, the case is over, and under Rule 56 of the Federal Rules of Civil Procedure, the judge must "state on the record the reasons for granting or denying the motion," which means writing a decision. But when the plaintiff wins, the judge writes a single word of endorsement"denied" - and the case moves on to trial. At the same time, plaintiffs rarely move for summary judgment. They bear the burden of proving all elements of the claim, particularly intent. Thus, to avoid summary judgment, a defendant need only show favorable contested facts in one element of a plaintiff's claim.

The result of this practice - written decisions only when plaintiffs lose — is the evolution of a one-sided body of law. Decision after decision grants summary judgment to the defendant or, more recently, on the heels of the Supreme Court's decisions in Bell Atlantic Corp. v. Twombly ${ }^{60}$ and Ashcroft v. Iqbal. ${ }^{61}$ dismisses the complaint. ${ }^{62}$ After the district court has described why the plaintiff loses, the case may or may not be appealed.

The structure of summary judgment opinions distorts the precedents further. Precedents are necessarily created in the decisional law when judges make rules, "mappings from the facts of the case . . to outcomes." ${ }^{63}$ In writing summary judgment decisions, the court is obliged to summarize the record, and in particular, to highlight the plaintiff's allegations, and grant inferences in favor of the plaintiff. As a result, when the court characterizes these facts as insubstantial stray remarks, or not part of a "severe and pervasive" pattern of discrimination, as an example, it affects more than the outcome in the case. The decision communicates an atmosphere of impunity. Discriminatory behavior will be tolerated and will not expose the employer to risk. Over and over, the opinions suggest, we will give the benefit of the doubt to the perpetrator, excusing his conduct, while subjecting the victim's perceptions to a higher standard. $^{64}$

The effects of Loser's Rules are exacerbated on appeal. While the standard of review of summary judgment orders is de novo, appellate courts rarely reverse district courts' decisions. Employers prevailed in $86 \%$ of published appellate opinions. ${ }^{65}$ Indeed, they are even more affected by the pool of cases they see - the selection effects of reviewing appeal after appeal of plaintiffs' losses. They do not see the strong cases that settle. They may see appeals from successful plaintiffs' verdicts, but those appeals are few and far between. In fact, their approach

\footnotetext{
${ }^{60} 550$ U.S. 544 (2007).

61556 U.S. 662 (2009).

${ }^{62}$ While the full effect of Iqbal and Twombly is not yet clear, it has increased the numbers of dismissals in general, and likely to do so with respect to discrimination cases. Kiel Robert Brennan-Marquez, The Epistemology of Twombly and Iqbal, 26 REGENT U. L. REV. 167, 169 n.9 (2013).

${ }^{63}$ Gillian K. Hadfield, Bias in the Evolution of Legal Rules, 80 GEO. L.J. 583, 587 (1992).

${ }^{64}$ Freeman, Legitimizing Discrimination, supra note 4, at 1056.

${ }^{65}$ Albiston, supra note 24, at 885.
} 
to appeals from successful verdicts may well reflect skewing I have described. A higher percentage of plaintiffs' verdicts are set aside as Clermont and Schwab found.

To be sure, what this analysis does not include are the cases that are settled. Arguably the better cases are removed from the pool by lawyers effected settlements for their clients. Marc Galanter has argued that because employers are "repeat players" while individual plaintiffs are not, the repeat players have every incentive to settle the strong cases and litigate the weak ones. ${ }^{66}$ But settlements take place in the "shadow of the law." ${ }^{, 67}$ It is not unreasonable to assume that the evolving case law figures into the settlement practices.

Loser's Rules explains not simply outcomes but the reasoning of the cases. If case after case recites the facts that do not amount to discrimination, decisionmakers have a hard time imagining the facts that comprise discrimination. And, they believe most of the claims are trivial. That attitude further distorts the evolution of substantive legal standards. Decision heuristics evolve, the kind of decision heuristics described above. As I described, "[c]ourts create decision heuristics to enable them to quickly dispose of complex cases. They then write decisions employing the heuristics and publish their opinions. In short order, other courts rely on the heuristics, which become precedent, and the process is repeated over and over again." 68 Obviously, discrimination heuristics, like all heuristic devices, runs the risk of false positives and false negatives.

When courts believe that most employment claims are meritless, as the judges do over time, they will be far, far more concerned with false positives - the wrongful accusation of discrimination, than false negatives, when discrimination is unredressed. Indeed, that concern wrongful accusations of discrimination, the transaction costs associated with it- has come to dominate the decisional law of civil procedure. ${ }^{69}$

\section{Conclusion}

Judges have created decisional rules that have gutted Title VII, rules not required by the statute (which, after all, says very little), its legislative history or the purposes of the Act. The patterns have garnered little attention from the popular media and as a consequence, there is little or no pressure for legislative change. Since Title VII was the very model of civil rights law reform legislation, it is critical to show how has this has happened and, more important, why?

\footnotetext{
${ }^{66}$ Galanter, supra note 11, at 101.. Indeed, he concluded that strategic settlement practices produce judicial interpretation of rights that favor the repeat players' interests, an effect which is exacerbated by Losers' Rules. Id. at 102.

${ }^{67}$ Robert H. Mnookin \& Lewis Kornhauser, Bargaining in the Shadow of the Law: The Case of Divorce, 88 YALE L.J. 950 (1979).

${ }^{68}$ Gertner, supra note 9, at 116.

${ }^{69}$ In Twombly, the Supreme Court concluded that a deficient complaint should "be exposed at the point of minimum expenditure of time and money by the parties and the court." Twombly, 550 U.S. at 558 (citation omitted) (internal quotation marks omitted). The Court in Iqbal reiterated this theme that "[1]itigation . . . exacts heavy costs in terms of efficiency and expenditure of valuable time and resources" and reasoned that a higher pleading standard was necessary to prevent groundless claims from imposing costs on defendants. See 556 U.S. at 685.
} 
How should these patterns be addressed? Should Title VII be amended yet again, creating a more explicit statute, more code like than a statement of principles, that would cabin judicial discretion? Or would regular monitoring of judicial decisions - like the N.D. Georgia Study make a difference, letting the judge know the patterns — if not overt the hostility — their decisions reflect? Or should we consider a new enforcement structure beyond the private attorneys' general model of Title VII? For example, would a more robust EEOC, with the power to adjudicate disputes and not just the power to investigate make a difference, staffed by hearing officers who can envision what discrimination looks like, in contrast to judges who plainly do not? One thing is clear: These patterns, the attitudes they reflect, should not be ignored. 